УдК 378.147:616.1/4:316.362:616.12-008.331.1-07/-085.225

DOI 10.11603/1811-2471.2018.v0.i3.9315

\title{
РЕКОМЕНДАЦІЇ ФІНСЬКОГО КЛІНІЧНОГО ПРОТОКОЛУ ЩОДО МЕДИКАМЕНТОЗНОЇ ТЕРАПІЇ АРТЕРІАЛЬНОÏ ГІПЕРТЕНЗІЇ У ВИКЛАДАННІ СІМЕЙНОЇ МЕДИЦИНИ НА ДОДИПЛОМНОМУ РІВНI
}

\author{
ДВНЗ «Тернопільський державний медичний університет імені І. Я. Горбачевського мОз України»
}

РЕзЮМЕ. Висока медико-соціальна значимість АГ у практиці лікаря первинної медичної допомоги (ПМд) визначає актуальність підвищення ефективності викладання цієї теми у рамках програми додипломної медичної освіти.

Мета - проаналізувати актуальні аспекти доцільності впровадження положень європейських клінічних протоколів ПМД (Фінляндія) щодо АГ у практику викладання дисципліни ЗП-СМ на етапі додипломної освіти.

Висновок. Європейські протоколи для первинної медичної допомоги (Фінляндія), створені за доказовими стандартами, є чіткими, структурованими, зрозумілими для менталітету лікарів України. Алгоритми призначення медикаментозної терапії залежно від ступеня тяжкості гіпертензії в амбулаторній практиці, викладені за фінськими протоколами, доцільно впроваджувати у клінічну практику і викладацький процес вивчення дисципліни «Загальна практика - сімейна медицина» на додипломному рівні вищої медичної освіти.

КлючовІ СлОВА: викладання сімейної медицини на додипломному рівні; артеріальна гіпертензія; клінічний протокол; медикаментозна терапія.

Вступ. Висока медико-соціальна значимість АГ у практиці лікаря первинної медичної допомоги (ПМД) визначає актуальність підвищення ефективності викладання цієї теми у рамках програми додипломної медичної освіти [2]. Відомо, що артеріальна гіпертензія (АГ), за визначенням ВООЗ, являє собою синдром постійно підвищеного систолічного та/або діастолічного артеріального тиску (АТ) [3, 5]. АГ становить серйозну медико-соціальну проблему внаслідок високого рівня смертності, інвалідизації, а також у зв'язку з високим рівнем захворюваності. У 2015 р. вона складала 122 на 100 тис. населення у Тернопільській області; 112 на 100 тис. -у Києві. Загалом в Україні налічується 9,7 млн хворих на АГ (без анексованого Криму та тимчасово окупованих територій Донецької та Луганської областей) $[1,4]$.

Викладання тематики щодо АГ триває протягом 6 років на різних кафедрах, починаючи з теоретичних засад на молодших курсах і практичних аспектів, які відпрацьовуються впродовж освоєння клінічних дисциплін. Однак значимість формування чіткого структурованого знання цієї нозології та її клініко-діагностично-лікувальних аспектів на рівні ПМД складно переоцінити. Саме на етапі ПМД мають відбуватися раннє виявлення АГ, проведення диференційної діагностики, оцінка лабораторно-інструментальних параметрів, формується план ведення хворого із визначенням маршруту у різних клінічних ситуаціях, визначаються і контролюються програми лікування i профілактики [1, 2].
Згідно з рекомендацією МОЗ України, все активніше у клінічній практиці використовуються європейські та інші (американські, канадські та ін.) клінічні протоколи, що розроблені у передових цивілізованих країнах світу на основі доказових стандартів, які використовують у медичній науці і практиці останніми роками $[6,7,8]$. Це повинно стосуватись і процесу викладання дисципліни «загальна практика-сімейна медицина» (3ПСМ). На кафедрі ПМСД та ЗП-СМ ТДМУ імені І. Я. Горбачевського плануємо використовувати фінські клінічні протоколи для ПМД, які входять до числа рекомендованих МОЗ. Фінські протоколи $\epsilon$ чіткими, структурованими, зрозумілими для менталітету лікарів України [9]. Важливим вважаємо той факт, що запит на використання саме цих протоколів надійшов від лікарів-практиків центру ПМД м. Тернополя, який $\epsilon$ клінічною базою кафедри.

Мета - проаналізувати актуальні аспекти доцільності впровадження положень європейських клінічних протоколів ПМД (Фінляндія) щодо артеріальної гіпертензії у практику викладання дисципліни ЗП-СМ на етапі додипломної освіти для засвоєння принципів і правил медикаментозної терапії препаратами основних фармакологічних груп.

Основна частина. Фінський клінічний протокол щодо медикаментозного лікування при АГ визначає основні положення про фактори, які слід враховувати при призначенні медикаментів: тяжкість гіпертензії, наявність ураження органамішені, супутні захворювання і призначені лікар- 
Огляди літератури, оригінальні дослідження, погляд на проблему, ювілеї

ські засоби (табл. 1), персональні дані, такі як вік і стать, вартість ліків, доказовість щодо прогнозу.

Студенти VI курсу повинні засвоїти, що при призначенні препаратів першої лінії досягається середнє зниження артеріального тиску (АТ) у відповідності з еквівалентними дозами (інгібіторів АПФ, блокаторів рецепторів ангіотензину (БРА), бета-блокаторів, діуретиків та блокаторів кальцієвих каналів), всі вони добре переносяться у малих дозах, а лікування цими засобами знижує частоту серцево-судинних подій (рівень доказовості (РД) А). Побічні ефекти, особливо від діуретиків, бета-блокаторів та блокаторів кальцієвих каналів, частіше пов'язані з більш високими дозами.

АТ можна також знизити за допомогою інгібітора реніну аліскірену, антагоністів альдостеро- ну, альфа-блокатора празозину та засобів центральної дії клонідину та моксонідину, які регулюють роботу симпатичної нервової системи; однак, немає наукових доказів про їх вплив на серцевосудинні події (препарати другої лінії).

До основних положень протоколу для ПМД належать також наступні: ефективність і переносимість лікарських препаратів можна покращити, використовуючи комбінацію кількох препаратів у малих дозах; комбінація двох препаратів знижує АТ ефективніше, ніж подвоєння дози одного препарату; більшість пацієнтів потребують комбінації ліків, щоб досягти мети лікування; лікування починається безпосередньо з комбінації лікарських засобів (2-4 препарати) у пацієнтів з високим ступенем ризику та при значному підвищенні АТ (> 180/110 мм рт. ст.).

Таблиця 1. Приклади антигіпертензивних препаратів першої лінії в різних умовах та за особливих обставин

\begin{tabular}{|c|c|}
\hline Умова & Антигіпертензивні препарати першої лінії \\
\hline \multicolumn{2}{|r|}{ Без пошкодження органа-мішені } \\
\hline Неускладнена гіпертензія & $\begin{array}{l}\text { Інгібітор АПФ, БРА, блокатор кальцієвих каналів, діуретик, бета-бло- } \\
\text { катор* }\end{array}$ \\
\hline \multicolumn{2}{|c|}{ Ураження органа-мішені / серцево-судинні захворювання } \\
\hline ГЛШ & Інгібітор АПФ, БРА, блокатор кальцієвих каналів, діуретик \\
\hline Мікроальбумінурія або протеїнурія & Інгібітор АПФ, БРА \\
\hline Порушення без альбумінурії & $\begin{array}{l}\text { Інгібітор АПФ, БРА; інші препарати, якщо потрібно, включаючи } \\
\text { діуретики) }\end{array}$ \\
\hline Історія інсульту & Інгібітор АПФ, БРА, блокатор кальцієвих каналів, діуретик \\
\hline Історія IM & Бета-блокатор, інгібітор АПФ (БРА, якщо інгібітор АПФ не показаний) \\
\hline Симптоматична ішемічна хвороба серця & Бета-блокатор, блокатор кальцієвих каналів, інгібітор АПФ \\
\hline Серцева недостатність & Інгібітор АПФ, БРА, діуретик, бета-блокатори, антагоніст альдостерону \\
\hline \multicolumn{2}{|r|}{ Фібриляція передсердь } \\
\hline Повторний & БРА, інгібітор АПФ, бета-блокатор \\
\hline Постійний & $\begin{array}{l}\text { бета-блокатор, верапаміл (зверніть увагу на те, що ці два медикамен- } \\
\text { ти не повинні поєднуватися). }\end{array}$ \\
\hline Периферійна судинна хвороба & інгібітор АПФ, блокатор кальцієвих каналів \\
\hline \multicolumn{2}{|r|}{ Немає ушкодження органів-мішеней } \\
\hline \multicolumn{2}{|r|}{ Особливі ситуації } \\
\hline Діабет & інгібітор АПФ, БРА, блокатор кальцієвих каналів, діуретик \\
\hline Гіпертензія під час вагітності & $\begin{array}{l}\text { Бета-блокатор, комбінація альфа- та бета-блокаторів (лабеталол), } \\
\text { блокатор кальцієвих каналів }\end{array}$ \\
\hline Астма & Блокатор кальцієвих каналів, БРА, сечогінний засіб \\
\hline
\end{tabular}

Примітки: 1. * -У зв'язку з гіперкінезією, симпатикотонією або стресом;

2. ** - Посібник Current Саге; Артеріальна гіпертензія, 2014 р. (з урахуванням змін).

Клінічний протокол, який дає розуміння європейських доказових підходів до лікування АГ, визначає основні моменти щодо використання антигіпертензивних препаратів першої лінії. Це важливо засвоїти субординаторам у ході практичних занять.

Наводимо контент щодо інгібіторів АПФ. Інгібітор АПФ $\epsilon$ найприйнятнішим початковим лікарським препаратом для багатьох груп пацієн- тів. Вони дуже ефективні, коли концентрація реніну в плазмі висока, наприклад, при тривалому застосуванні сечогінного засобу. Супутнє призначення блокатора кальцієвих каналів або діуретика значно підвищує ефективність інгібітора АПФ. Антигіпертензивне лікування хворих на цукровий діабет або захворювання нирок повинне завжди включати інгібітор АПФ або БРА. Інгібітори АПФ покращують загальний прогноз пацієнтів з арте- 
Огляди літератури, оригінальні дослідження, погляд на проблему, ювілеї

ріосклерозом, тому інгібітори АПФ та БРА-препарати рекомендують застосовувати як антигіпертензивні препарати першої лінії. Інгібітор АПФ слід призначати разом з бета-блокатором усім пацієнтам з ішемічною хворобою серця та гіпертензією.

Рекомендовані препарати цієї групи: еналаприл 10-40 мг/добу; каптоприл 50-150 мг/добу; квінаприл 10-40 мг/добу; лізиноприл 10-40 мг/ добу; периндоприл 5-10 мг/добу; раміприл 2,510 мг/добу.

3 небезпечних ефектів необхідно враховувати такі: кашель у 20 \% хворих, висипання, абдомінальна патологія, запаморочення, головний біль, порушення смаку, ангіоедема.

Протипоказання для застосування інгібіторів АПФ: двосторонній стеноз ниркової артерії або стеноз артерії, що кровопостачає єдину нирку; ниркова недостатність у літніх пацієнтів; якщо розпочато лікування, слід уважно стежити за вмістом калію та креатиніну (перша перевірка повинна бути зроблена через тиждень після початку лікування); серйозний нелікований стеноз аорти або мітрального клапана; вагітність; ангіоневротичний набряк.

Необхідно мати на увазі також наступні застереження, які вказані у протоколі: калій та креатинін плазми слід перевіряти через місяць після початку лікування. Якщо пацієнт має ознаки або симптоми периферійного атеросклерозу або ниркової недостатності, перша перевірка повинна бути проведена через тиждень після початку лікування. Якщо у пацієнта літнього віку збільшився креатинін у плазмі до рівня вище 150 мкмоль/л або вище 180 мкмоль/л, слід спочатку переоцінити споживання та дозу, а препарат, можливо, вилучити.

Стосовно блокаторів рецепторів ангіотензину (БРА) необхідно брати до уваги наступні положення. БРА-препарати впливають на систему ренін-ангіотензин-альдостерону, але у спосіб, який відрізняється від інгібіторів АПФ. Вони підходять для пацієнтів, у яких виникли побічні ефекти внаслідок застосування інгібіторів АПФ.

Препарати та дозування: лозартан 50-100 мг один раз на добу; валстартан 80-320 мг один раз на день; кандесартан по 8-32 мг один раз на добу; епросартан по 600 мг один раз на день; телмісартан 40-80 мг один раз на день; олмесартан по 10-40 мг один раз на день.

Ефект БРА можна значно збільшити шляхом додавання сечогінного засобу. БРА-препарати добре переносяться, побічні ефекти легкі. Вони можуть бути альтернативою для пацієнтів, у яких інгібітори АПФ викликають кашель. Протипоказання такі ж, як для інгібіторів АПФ, необхідно слідкувати за рівнем креатиніну та електролітів, як для інгібіторів АПФ.

Контент для засвоєння щодо діуретиків у клінічному протоколі наведено нижче. Діуретики особливо підходять для літніх жінок (профілактика остеопорозу за допомогою тіазидних діуретиків (РД С) і для пацієнтів із ознаками затримки солі та рідини або набряком, пов'язаним з серцевою недостатністю. Вони також можуть бути використані в комбінації з іншими антигіпертензивними препаратами.

Препарати діуретиків та їх дозування: гідрохлоротіазиду 12,5-25 мг один раз на день, початкова доза для літніх пацієнтів - 12,5 мг/добу; амілорид завжди використовується як добавка до гідрохлортіазиду, за умови, що рівень креатиніну $\epsilon$ нормальним і немає ризику гіперкаліємії. Гіпокаліємії слід уникати, особливо якщо пацієнт хворіє на ССЗ або використовує дигоксин; індапамід (модифікований випуск) 1,5 мг на добу $\epsilon$ альтернативою гідрохлоротіазиду. Проте при застосуванні індапаміду, порівняно з невеликими дозами тіазидів, не виявлено виражених переваг, і індапамід у деяких пацієнтів може спричинити серйозний дисбаланс електролітів; фуросемід застосовують лише при нирковій недостатності (плазмовий креатинін> 150 мкмоль/л).

До негативних впливів (при досить високих дозах) належать наступні: гіпокаліємія, гіпонатріємія, гіпомагніємія, гіперурикемія, гіперглікемія, збільшення концентрації тригліцеридів, зменшення рівня холестерину ЛПВЩ; на практиці вплив на ліпіди незначний; підвищена резистентність до інсуліну у деяких пацієнтів

Протипоказання до призначення діуретиків: калійзберігаючих діуретиків слід уникати при нирковій недостатності через ризик гіперкаліємії; вони не $\epsilon$ препаратом першої лінії для пацієнтів із подагрою або гіперурикемією, метаболічним синдромом або діабетом. Рівні калію і натрію плазми слід перевіряти через 1-2 місяці після початку лікування. Якщо концентрація $\epsilon$ нормальною, достатньо проводити моніторинг один раз на рік.

Щодо блокаторів кальцієвих каналів (БКК) необхідно запам'ятати наступні положення. Засоби блокування кальцієвих каналів підходять для людей похилого віку, фізично активних пацієнтів і хворих з ішемічною хворобою серця, якщо бетаблокатори протипоказані. Ефект зниження АТ хороший, особливо у пацієнтів похилого віку. БКК не вимагають лабораторних аналізів для контролю безпечності лікування. БКК Dihydropyridine може полегшити симптоми хвороби Рейно. Дилтіазем і верапаміл можуть запобігати аритмії передсердь та уповільнити швидкість шлуночків при фібриляції передсердь. 
Огляди літератури, оригінальні дослідження, погляд на проблему, ювілеї

Препарати БКК та їх дозування: БКК з судинними ефектами (похідні дигідропіридину) - амлодипін 5-10 мг/добу; фелодипін 5-10 мг/добу, ізрадипін 5-10 мг/добу, лерканідипін 10-20 мг/добу, ніфедипін 20-60 мг/добу, нілвадипін 8-16 мг/добу, нізолдипін 10-40 мг/день; БКК з переважно серцевим ефектом - дилтіазем 180-360 мг/добу, верапаміл 120-480 мг/добу.

Негативні ефекти БКК: головний біль, головокружіння, набряк ніг, зливна еритема шкіри, гінгівальна гіперплазія, запори, дефекти серцевої провідності.

Верапаміл не можна застосувати в комбінації з бета-блокаторами, верапаміл і дилтіазем не слід застосовувати при серцевій недостатності та АВ-блокаді.

Інформація про бета-блокатори ББ у фінському протоколі для первиної допомоги подана наступна. ББ - антигіпертензивний препарат першої лінії для пацієнтів з ішемічною хворобою серця або іншими показаннями для ББ, наприклад, аритмією. Вони підходять для молодих гіперактивних пацієнтів, які мають симптоми стресу, такі як пітливість, емоційне напруження та серцебиття. Вони також можуть бути використані в комбінації з іншими антигіпертензивними препаратами. Карведилол і лабеталол можуть викликати постуральну гіпотензію у літніх пацієнтів. Високоселективні ББ замінили неселективні та менш селективні ББ.

Препарати ББ та їх дозування: високоселективні ББ найкраще переносяться і не впливають на ліпіди (бісопролол 5-10 мг один раз на день, бетаксолол 10-20 мг один раз на день), переносимість та ефективність краща у селективних ББ, ніж у неселективних (метопролол 100-200 мг/добу, небіволол 5 мг/добу (також має судинорозширювальну дію), альфа- і бета-блокатори (судинорозширювальна дія), карведилол 25 мг один раз на день, лабеталол 200-800 мг/добу).

Негативні ефекти ББ: брадикардія, погіршення нестабільної серцевої недостатності, проте при поєднанні з інгібітором АПФ та діуретиком ББ (бісопролол, карведилол, метопролол, небіволол) знижують кардіальну смертність. Серцева недостатність $\epsilon$ показанням для призначення ББ, лікування ББ слід розпочинати з невеликої дози, повільно її збільшуючи; дефекти провідності, синдром слабкості синусового вузла; ББ можуть посилити симптоми тяжкої оклюзійної хвороби периферійної артерії, але їх можна застосовувати при помірних і середньої тяжкості захворюваннях периферійних артерій; астма (при необґрунтованих обставинах слід вибрати дуже селективний бета ${ }_{1}$-блокатор і активний бета сну; гіпоглікемія при цукровому діабеті (симпто- ми маскуються!); знижена толерантність до фізичних навантажень, стомлюваність, імпотенція.

Абсолютні та відносні несприятливі ефекти ББ, особливо при застосуванні сечогінного засобу, слід уникати як препарат першої лінії у пацієнтів з метаболічним синдромом або підвищеним ризиком розвитку цукрового діабету.

Важливою для засвоєння і практичного застосування за необхідності $\epsilon$ інформація щодо препаратів другої лінії, подана у європейському клінічному протоколі для лікарів ПМД.

Симпатолітичні засоби центральної дії застосовуються значно рідше через їх численні несприятливі ефекти (вони використовуються як альтернативні препарати у тих випадках, коли інші ліки протипоказані або неефективні).

Препарати симпатолітичних засобів центральної дії: клонідин 75-150 мкг тричі на день, моксонідин 0,2-0,4 мг один раз на день, максимальна доза 0,6 мг щодня у розділених дозах (тобто 0,4 мг + 0,2 мг).

Антагоністи альдостерону ефективні при гіпероальдостеронізмі; поліпшення прогнозу хворих з серйозною серцевою недостатністю (РД А). При персистентній гіпертензії спіронолактон (12,5-25 мг/добу) може бути ефективним, але його слід обережно застосовувати, ретельно контролюючи концентрацію калію та креатиніну в плазмі, якщо пацієнт також використовує інгібітор АПФ або БРА. Концентрацію калію плазми слід ретельно контролювати.

Інші вазодилатаційні препарати застосовують рідко, оскільки БКК і інгібітори АПФ також мають вазодилатаційні ефекти (іх використовують як альтернативні препарати у тих випадках, коли інші ліки непридатні).

Празозин має наступні побічні ефекти: постуральна гіпотензія, набряк, часте сечовипускання, пріапізм, серцебиття.

Інгібітор реніну аліскірен (150-300 мг один раз на день) можна застосовувати в комбінації 3 кількома іншими антигіпертензивними препаратами. Одночасне використання з інгібітором АПФ або БРА не рекомендується і протипоказане пацієнтам із діабетом або з середньої тяжкості чи тяжкою нирковою недостатністю.

Важливими для відпрацювання на практичних заняттях $\epsilon$ також правила поєднання антигіпертензивних препаратів, що мають встановлений РД і внесені до європейського протоколу: для посилення комплементарного механізму дії різних антигіпертензивних препаратів; для зменшення несприятливих ефектів; для поліпшення результатів лікування.

Найкращі комбінації - інгібітор АПФ або БРА і блокатор кальцієвих каналів; інгібітор АПФ або 
Огляди літератури, оригінальні дослідження, погляд на проблему, ювілеї

БРА та сечогінний засіб (або обмеження солі до менш ніж 5 г на добу); бета-блокатор та блокатор кальцієвих каналів дигідропіридинового ряду; блокатор кальцієвих каналів та сечогінний комплекс.

Можливі комбінації - бета-блокатори та діуретики (або обмеження солі до менш ніж 5 г на добу) не слід застосовувати як препарат першої лінії у пацієнтів з метаболічним синдромом; бетаблокатор та інгібітор АПФ не $є$ оптимальною комбінацією стосовно антигіпертензивного ефекту, але може застосовуватися, якщо вона призначена з інших причин (наприклад, ішемічна хвороба серця та серцева недостатність $\epsilon$ показаннями для ББ).

Комбінації, які слід уникати - бета-блокатори та верапаміл або дилтіазем може викликати надмірну брадикардію, гіпотензію або серцеву недостатність у літніх пацієнтів та у пацієнтів з порушеннями функції міокарда.

Комбінації ліків, які пригнічують систему ренін-ангіотензину (БРА, інгібітори АПФ, інгібітори реніну, антагоністи альдостерону) не слід застосовувати при лікуванні гіпертензії, оскільки вони збільшують частоту несприятливих ефектів, не зменшуючи частоту серцево-судинних подій.

Потрійна терапія - діуретик, інгібітор АПФ / БРА, блокатор кальцієвих каналів / бета-блокатор; бета-блокатор, вазодилатаційний блокатор кальцієвих каналів і діуретик.

Комбінації від чотирьох до п'яти лікарських засобів - діуретики, інгібітор АПФ/БРА, блокатор кальцієвих каналів, бета-блокатор; центральної дії симпатолітичний препарат (моксонідин, клонідин) може бути доданий у разі необхідності. Спіронолактон $\epsilon$ ефективним додатковим препаратом при гіперальдостеронізмі і часто може замінити інгібітор АПФ.

Зниження або припинення антигіпертензивного лікування проводиться за наступними принципами. Може розглядатися при легкій неускладненій АГ, якщо протягом 12 місяців АТ залишається менше 120/80 мм рт. ст. при застосу- ванні препарату та зміні способу життя. Після зменшення дози АТ слід перевіряти щомісяця. Після припинення лікування АТ слід перевіряти щомісяця протягом 6 місяців, а потім постійно кожні 3-4 місяці, оскільки АГ часто повертається протягом багатьох років.

Небезпека припинення медикаментозного лікування $\epsilon$ мінімальною за умови, що подальше спостереження не буде знехтуване. Потреба відновити лікування зазвичай стає очевидною протягом 2-3 місяців, але іноді лише через кілька років. Важливою $€$ постійна модифікація способу життя.

Причинами, зменшення дози або відміни антигіпертензивних ліків $\epsilon$ наступні: зниження стресогенності; зниження ваги; позитивні зміни інших чинників, що сприяють АГ, якщо показання до початку антигіпертензивного лікування були невідповідними; старіння та допуск до довгострокової інституційної допомоги часто "виліковують» неускладнену АГ, у цих випадках діуретики, зокрема, можуть легко викликати ортостатичну гіпотензію та інші несприятливі ефекти, які погіршують якість життя; серцева недостатність після інфаркту міокарда.

Висновок. Європейські протоколи для первинної медичної допомоги (Фінляндії), створені за доказовими стандартами, $\epsilon$ чіткими, структурованими, зрозумілими для менталітету лікарів України. Алгоритми призначення медикаментозної терапії залежно від ступеня тяжкості гіпертензії в амбулаторній практиці, викладені за фінськими протоколами, доцільно впроваджувати у клінічну практику і викладацький процес вивчення дисципліни «Загальна практика-сімейна медицина» на додипломному рівні вищої медичної освіти.

Перспективи подальших розробок - впровадити у викладацький процес алгоритми призначення диференційованої медикаментозної терапії інших нозологій на етапі первинної медичної допомоги згідно з вимогами європейських клінічних протоколів.

\section{ЛІТЕРАТУРА}

1. Наказ МОЗ України від 13.06.2016 №564 «Уніфікований клінічний протокол первинної, вторинної (спеціалізованої) та третинної (високоспеціалізованої) медичної допомоги. Профілактика серцево-судинних захворювань».

2. Сімейна медицина : навчальнй посібник / [Гощинський В. Б., Бабінець Л. С., Стародуб Є. М. та ін.]; за ред. В. Б. Гощинського, Л. С. Бабінець, Є. М. Стародуба. 2-ге вид., доп. і переро6. - Тернопіль : ТДМУ, 2014. 1162 c.

3. Про затвердження клінічних протоколів надання медичної допомоги за спеціальністю «Кардіологія»: Наказ МОЗ України від 03.07.2006 № 436. [Електронний ресурс]. Режим доступу: http://moz.gov.ua/ua/portal/ dn_20060703_436.html.

4. Шлант Р.К. Клиническая кардиология/Р. К. Шлант, Р. В. Александер. - М. - СПб. : Издательство БИНОМ Невский проспект, 2017. - 576 с.

5. 2013 ESH/ESC Guidelines for the management of arterial hypertension // Eur. Heart J. -2013. - Vol. 34 (28). - P. 2159-2219. 
Огляди літератури, оригінальні дослідження, погляд на проблему, ювілеї

6. $2013 \mathrm{ESH} / \mathrm{ESC}$ guidelines for the management of arterial hypertension: the Task Force for the Management of Arterial Hypertension of the European Society of Hypertension (ESH) and of the European Society of Cardiology (ESC) / G. Mancia, R. Fagard, K. Narkiewicz [et al.] // Eur. Heart J. 2013. - Vol. 34 (28). - P. 2159-2219. PubMed.

7. European Guidelines on cardiovascular disease prevention in clinical practice (version 2012). The Fifth Joint Task Force of the European Society of Cardiology and Other Societies on Cardiovascular Disease Prevention in Clinical Practice (constituted by representatives of nine societies and by invited experts) / J. Perk, G. De Backer, H. Gohlke [et al.] // Eur. Heart J. 2012. - Vol. 33 (13). P. 1635-1701. PubMed.

8. The Cochrane Collaboration The Cochrane Library http://www.cochrane.org/.

9. The Finnish Medical Society Duodecim https:// www.duodecim.fi/.

\section{REFERENCES}

1. Nakaz MOZ Ukrainy vid 13.06.2016 №564 "Unifikovanyi klinichnyi protokol pervynnoi, vtorynnoi (spetsializovanoi) ta tretynnoi (vysokospetsializovanoi) medychnoi dopomohy. Profilaktyka sertsevo-sudynnykh zakhvoriuvan" [Order of the Ministry of Health of Ukraine dated June 13, 2016, No. 564 "Unified clinical protocol of primary, secondary (specialized) and tertiary (highly specialized) medical aid. Prevention of Cardiovascular Diseases"] (2016). [in Ukrainian].

2. Hoshchynskyi, V.B., Babinets, L.S., Starodub, Ye.M. (2014). Simeina medytsyna: navchalnyi posibnyk [Family medicine: educational manual]. Ternopil: Ukrmedknyha [in Ukrainian].

3. Nakaz MOZ Ukrainy vid 03.07.2006 №436 “Pro zatverdzennia klinichnykh protokoliv nadannia medychnoi dopomohy za spetsialnistiu "Kardiolohiia" [Order of the Ministry of Health of Ukraine of 03.07.2006 No.436 "About the approval of clinical protocols for the provision of medical care in the specialty "Cardiology"]. - Retrieved from: http://moz.gov.ua/ua/portal/dn_20060703_436.html [in Ukrainian].
4. Shlant, R.K., \& Aleksander, R.V. (2017). Klinicheskaya kardiologiya [Clinical cardiology]. Moscow: St. Petersburg: Izdatelstvo BINOM [in Russian].

5. $2013 \mathrm{ESH} / \mathrm{ESC}$ Guidelines for the management of arterial hypertension. (2013). Eur. Heart J., 34 (28), 2159-2219.

6. Mancia, G., Fagard, R., Narkiewicz, K. (2013). 2013 ESH/ESC guidelines for the management of arterial hypertension: the Task Force for the Management of Arterial Hypertension of the European Society of Hypertension (ESH) and of the European Society of Cardiology (ESC). Eur. Heart J., $34(28), 2159-2219$.

7. Perk, J., De Backer, G., Gohlke, H. (2012). European Guidelines on cardiovascular disease prevention in clinical practice (version 2012). The Fifth Joint Task Force of the European Society of Cardiology and Other Societies on Cardiovascular Disease Prevention in Clinical Practice (constituted by representatives of nine societies and by invited experts). Eur. Heart J., 33 (13), 1635-1701.

8. The Cochrane Collaboration The Cochrane Library. Retrieved from: http://www.cochrane.org/.

9. The Finnish Medical Society Duodecim. - Retrieved from: https://www.duodecim.fi/.

\title{
РЕКОМЕНДАЦИИ ФИНСКОГО КЛИНИЧЕСКОГО ПРОТОКОЛА ПО МЕДИКАМЕНТОЗНОЙ ТЕРАПИИ АРТЕРИАЛЬНОЙ ГИПЕРТЕНЗИИ В ПРЕПОДАВАНИИ СЕМЕЙНОЙ МЕДИЦИНЫ НА ДОДИПЛОМНОМ УРОВНЕ
}

\author{
๑Л. С. Бабинец, Ю. Я. Коцаба
}

\author{
ГвУЗ «Тернопольский государственный медицинский университет имени И. Я. Горбачевского \\ МЗ Украины»
}

РЕЗЮМЕ. Высокая медико-социальная значимость АГ в практике врача первичной медицинской помощи (ПМП) определяет актуальность повышения эффективности преподавания этой темы в рамках программы додипломного медицинского образования.

Цель - проанализировать актуальные аспекты целесообразности внедрения положений европейских клинических протоколов ПМП (Финляндия) по АГ в практику преподавания дисциплины ОП-СМ на додипломном этапе образования.

Выводы. Европейские протоколы для первичной медицинской помощи (Финляндия), созданные по доказательным стандартам, являются четкими, структурированными и понятными для менталитета врачей Украины. Алгоритмы назначения медикаментозной терапии в зависимости от степени тяжести гипертензии в амбулаторной практике, изложенные по финским протоколам, целесообразно внедрять в клиническую практику и преподавательский процесс изучения дисциплины «Общая практика - семейная медицина» на додипломном уровне высшего медицинского образования.

КЛЮЧЕВЫЕ СЛОВА: преподавание семейной медицины на додипломном уровне; артериальная гипертензия; клинический протокол; медикаментозная терапия. 
Огляди літератури, оригінальні дослідження, погляд на проблему, ювілеї

\section{RECOMMENDATIONS OF THE FINNISH CLINICAL PROTOCOL ABOUT DRUG THERAPY OF ARTERIAL HYPERTENSION IN THE TEACHING OF FAMILY MEDICINE ON THE PREGRADUATE LEVEL}

@L. S. Babinets, Yu. Ya. Kotsaba

\section{Horbachevsky Ternopil State Medical University}

SUMMARY. Introduction. The high medical and social significance of hypertension in the practice of the primary care physician (PCP) determines the relevance of improving the teaching effectiveness of this topic within the framework of the pregraduate medical education program.

The aim is to analyze the actual aspects of expediency of introducing the provisions of the European clinical protocols of PCP (Finland) regarding arterial hypertension into the practice of teaching discipline GP-FM at the stage of pregraduation education.

Conclusion. European protocols for primary health care (Finland), established on the basis of evidence, are clear, structured and understandable for the mentality of doctors in Ukraine. The algorithms for the appointment of medical therapy, depending on the severity of hypertension in ambulatory practice, set out in the Finnish protocols, should be introduced into clinical practice and educational process of studying the discipline "General Practice - Family Medicine" at the pregraduate level of higher medical education.

KEY WORDS: teaching of family medicine at the pregraduate level; arterial hypertension; clinical protocol; drug therapy.

Отримано 16.08.2018 